\title{
Sobre alguns curculionideos que vivem nos bambús.
}

pelo

\author{
DR. A. DA COSTA LIMA. \\ (Com as estampas 11 e 12).
}

I.

\section{On some curculionidae living in bamboo stems. \\ by}

\author{
DR. A. DA COSTA LIMA.
}

(With the plates 11 and 12).

I.

Uma pequena especie cultivada de bambú, vulgarmente conhecida aqui sob o nome de cana da India, é sujeita aos ataques do Erethistes lateralis (BHIN.) como verifiquei em material colnido em Petropolis pelo Dr. OSWALDO CRUZ.

A larva e a imajem alimentam-se da medula que reveste as cavidades dos internodios, onde o ovo é depositado pelo coleoptero femea depois de ter, com o rostro, perfurado a parede.

Assim uma femea poe varios ovos num mesmo colmo porem apenas um em cada internodio. Depois de feita a postura em alguns internodios a femea faz, abaixo daquele que está mais perto da raiz, um circulo de furos muito aproximados que, mais cêdo
A small cultivated kind of bamboo, known here as indian cane, frequently suffers from the attacks of the Erethistes lateralis (BHN.), as I was able to show by studying cane fragments brought from Petropolis by Dr. OSWALDO CRUZ.

The larva, as well as the imago, feed on the soft substance lining the cavities of the bamboo joints where the egg is deposited by the female beetle after piercing the stem by means of its rostrum. It lays in several adjoining internodes, but only one egg in each, and then proceeds to bore a circle of contiguous holes in the wall of the joint, underneath the lowest one which includes an egg. 
ou mais tarde, determinam a quéda da parte superior do colmo.

Cada fragmento caido consiste em 3 ou mais internodios fechados, mostrando, cada um, um furo lateral e, em uma ou em ambas as extremidades, a fratura circular que foi preparada pelo processo descrito.

A perfuração lateral apresenta-se fechada por fibras que fazem saliencia no exterior, parecendo ser isto tambem devido ao trabatho do coleoptero. (Fig. 1)

No internodio o ovo é encontrado colado á parede, perto do orificio interno.

No fim de poucos dias saem as larvas que se alimentam roendo a camada interna da parede do internodio, emquanto que os detritos e escrementos ficam na cavidade.

Passando larvas criadas na cana da India para o bambú comum, ainda verde, estas nada sofrem; o mesmo verifiquei com as imajens que tambem se alimentam como as larvas.

Não posso determinar a duração do periodo larvario, pois, até hoje, apenas observei algumas phases da metamorfose deste inseto; julgo que dura mezes.

Quanto á posição sistematica do coleoptero em questão, trata-se do Ercthistes lateralis (BHN.) curculionideo do grupo Cholina.

\section{Erethistes lateralis (BHN.) 1836 (Fig 2 e 3)}

SCHOENHERR. Genera et species Curculionidum. T. 3o, pt. 2a, pg. 560. T. 8o, pt. 1a. pg. 5 (Cholus).

- LACORDAIRE. Gen. des coléoptères, 7, p. 47 (Perideraeus).

- PASCOE, F. P. Contributions towards a knowledge of the Curculionidae. Part. III. p. 471-The Journal of the Linnean Society. Zoology. London. 11, 1873 (Erethistes).

"Elongato-ovatus, niger, pube pallidaadspersus, thorace triangulari, remote granulato, vitta infra-laterali silaceo-squamosa, ornato, elytris rude punctato-striatis, corpore subius utrinque silaceo-lineato.
Sooner or later the stem will break at this place and drop on the ground.

The shed fragments are formed by three or more closed joints, each one with a lateral opening, and show on the under end or on both a circular line of fracture due to the work of the beetle.

The lateral openings are closed by interworen fibres forming a slight elevation on the outside. This also seems to be the work of the beetle. (Fig. 1).

In the joint the egg is found sticking to the wall close by the opening.

The larvae hatch after five days and consume the inner layer of the joint, while detritus and excrements drop in the cavity.

Larvae bred in the indian cane may be transferred without suffering to a green stem of the common bamboo, which also may be used as food for the imago.

The duration of the larval period is not determined yet but may be sefely assumed to last some months at the least.

As for the systematic position of our beetle: it is the Erethistes lateralis (BHN.) curculionid belonging to the Cholina group.

\section{Erethistes lateralis (BHN.) 1836 (Fig. 2 and 3).}

SCHOENHERR. Genera et species Curculionidum. T. 3, pt. 2. pg. 560. T. 8. pt. 1., pg. 5 (Cholus).

- LACORDAIRE. Gen. des coléoptères, 7, p. 47 (Perideraeus).

- PASCOE. F. P. Contributions towards a knowledge of the Curculonidae. Part. III. p. 471. The Journal of the Linnean Scciety. Zoology. London, 11, 1873 (Erethistes).

"Elongato-ovatus, niger, pube pallida adspersus, thorace triangulari, remote granulato, vitta infra-laterali silaceo-squamosa, ornato, elytris rude punctato-striatis, corpore subtus untrinque silaceo-lineato. 

Holm.

Patria: Brasilia. Mus. Reg. Acad. Scient.

Habitus Choli albicincti, sed dimidio major. Caput mediocre, rotundatum, nigrum rugoso-punctatum, supra pube pallida parce adspersum, subtus silaceo-squamosum, inter oculos leviterimpressum ; oculi magni, rotundati, parum prominuli, nigri, nitidi ; rostrum longitudine fere dimidii corporis, tenue, arcuatum, apicem versus nonnihil ampliatum, deplanatum, nigrum, basi striolato-rugosum, apicem versus subtiliter remote punctulatum, nitidum. Antennae rostro breviores, tenues, nigrae, nitidæ, parce pilosae, clava oblongo-ovata, acuminata, atra. Thorax latitudine baseos nonnihil brevior, a basi apicem versus angustatus, antice subtruncatus, postice leviter bisinuatus, tuberculis minus crebris, rctundis, modice elavatis, obsitus, niger, pube pallida parce adspersus, vitta infra-laterali silaceo-squamosa, ornatus Scuttelum oblongum, nigrum, obsolete punctulatum. Elytra sub-obconica, basi truncata; antice thorace non latiora, et illo vix duplo longiora, a basi apicem versus sensim angustata, apice ipso singulatim obtuse rotundata, supra depressa, rude at minus regulariter punctato-striata, nigra, pube depressa pallida parce adspersa. Corpus subtus nigrum, obsolete punctulatum, pube tenui pallida adspersum, utrinque linea lata, postice abreviata, silaceo-squamosa, decoratum. Pedes elongati, nigri, pube pallida parce obsiti; antici longiores; femoribus omnibus modice clavatis, subtus dente acuto armatis, posticis ad basin supra silaceo-squamosis; tibiis parum arcuatis; tarsis dilatatis, subtus obscure umbrinospongiosis.-BHN."

Comprimento. 13,5 $\mathrm{mm}$.

Larva (Figura 4). Apode, esbranquiçada; cabeça ocracea com um sulco mediano que percorre a parte superor e se bifurca adiante limitando uma area triangular de base anterior.

Algumas cerdas finas na face inferior dos segmentos toraxicos e outras menores irregularmente espalhadas em todo o resto do corpo.
Patria: Brasilia. Mus. Reg. Acad. Scient. Holm.

Habitus Choli albicincti, sed dimidio major. Caput mediocre, rotundatum, nigrum, rugoso-punctatum, supra pube paliida parce adspersum, subtus silaceo-squamosum, inter oculos leviter impressum; oculi magni, rotundati, parum prominuli, nigri, nitidi; rostrum longitudine fere dimidii corporis, tenue, arcuatum, apicem versus nonnihil ampliatum, deplanatum, nigrum, basi striolato-rugosum, apicem versus subtiliter remotepunctulatum, nitidum. Antennae rostro breviöes, tenues, nigrae, parce pilosae clava oblongo-ovata, acuminata, atra. Thorax latitudini baseos nonnihil brevior, a basi apicem versus angustatus, antice sub-truncatus, postice leviter bi-sinuatus, tuberculis minus crebris, rotundis, modice elevatis, obsitus, niger, pube pallida parce adspersus, vitta infra-lateralis silaceo-squamosa, ornatus. Scutellum oblongum, nigrum, obsolete punctulatum. Elytra subobconica, basi truncata; antice thorace non latiora, et illo vix duplo longiora, a basi apicem versus sensim angustata, apice ipso singulatim obtuse rotundata, supra depressa, rude at minus regulariter punctato-striata, nigra, pube depressa pallida parce adsperss. Corpus subtus nigrum, obsolete punctulatum, pube tenui pallida adspersum, utrinque linea lata, postice abbreviata, silaceo-squamosa, decoratum. Pedes elongati, nigri, pube pallida parce obsiti; antici longiores; femoribus omnibus modice clavatis, subtus dente acuto armatis, posticis ad basin supra silaceosquamosis; tibiis parum arcuatis; tarsis dilatatis, subtus obscure umbrino-spongiosis BHN.»

Length. $13,5 \mathrm{~mm}$.

Larva (Fig. 4). Apode, whitish; head ochraceous with a longitudinal furrow simple and median on the posterior part of the superior face, bifurcating anteriorly and limiting a triangular area with anterior base.

Some bristles on ventral face of thoraxic segments and shorter ones widely disseminated on all the other segments of the body. 
Ovo. Branco amarelado, cilindrico, com as extremidades arredondadas.

Comprimento. $3 \mathrm{~mm}$.

O Erethistes lateralis tem um inimigo natural numa especie de Prodecatoma (n. especie) hymenoptero da super-familia Chalcidioidea ASHM.

Logo que a femea do Erethistes poz o ovo, o hymenoptero deposita o seu em cima do mesmo. A larva do Prodecatoma nasce em primeiro lugar e desenvolve-se completamente a custa do ovo do Erethistes; depois transforma-se em nimfa da qual, sae a imajem. Esta, para sair da cavidade do internodio, abre um canal cilindrico na parede, frequentemente no meio do furo obliterado. Não posso precisar exatamente o tempo entre o dia da postura e a saida da imagem, entretanto, não deve exceder a 15 dias.

\section{Prodecatoma Cruzi, n. especie.}

Macho (Fig 5). Quasi todo o corpo preto metalico; olhos de cor purpurea muito escura; ocelos da mesma cor; parte inferior do abdome e pernas de um ferruginoso mais ou menos claro; os primeiros pares de patas com trocanteres, femures e tibias de cor ferruginosa mais ou menos escura; tarsos do par anterior com a mesma coloração dos outros segmentos; os do par medio de cor amarela esbranquiçada com a extremiaade escura; femures das pernas posteriores pretos, menos as extremidades que são ferruginosas escuras; tibias ferruginosas mais escuras na metade superior; tarsos brancos com o articulo apical escuro.

Azas hialinas, com nervuras testaceas; nervura marjinal comprida; post-marjinal mais longa que a metade da marjinal; estigmal igual a metade da mesma.

Cabeça, torax e quadris apresentam toda a superficie umbilico-pontuada, coberta com pequenos pêlos brancos.

Antenas: comprimento do escapo quasi igual a soma do pedicelo e 10 articulo do funiculo; $2^{\circ}, 3^{\circ}$ e 40 articulos iguaes, um pouco maiores que o $10 ; 5^{\circ} \mathrm{um}$ pouco menor e $6^{\circ}$ um pouco naior que o primeiro; os 5
Egg. Yellowishw hite, cylindrical on the middle and rounded on both ends.

Length. $3 \mathrm{~mm}$.

I discovered a natural enemy of the Erethistes lateralis in an species of Prodecatoma (P. Cruzi, n. sp.) hymenopteron of the super-family Chalcidiodea ASHM.

Immediately after the oviposition of Erethistes the hymenopteron deposits his egg on that of Erethistes. The Prodecatoma larva hatches first and feeds on the Eresthistes egg; when all the contents of the egg is consumed the larva is full grown and pupates. The imago gets out to the exterior by boring a cylindrical canal through the wall of the stem, often using the perfuration made and closed by the beetle. I can not state exactly the time between the oviposition and ecdysis, but it does not exceeds a fortnight.

\section{Prodecatoma Cruzi n. sp.}

Male (Fig. 5). Almost entirely metallic black; eyes and ocelli deep purpureous; legs and ventral aspect of abdomen show various shades of ferrugineous; trochanters, femora and tibiae of the first pair rust colour, darker or lighter; tarsi of the first pair in colour like the other segments of same leg; femora of hind legs black, only the ends dark ferrugineous; tibiae ferrugineous darker on the superior half; tarsi white with apical article darker. Wings hyaline with testaceous veins; marginal vein long; stigmal vein half as long as marginal; post-marginal somewhat longer than the second. Head, thorax and coxae umbilicate-punctate with small white hairs.

Antennae: length of the scapus equal to that of pedicellus added to that of first joint of the funicle; 2 nd, $3 \mathrm{rd}$ and 4 th joirts of the funicle of the same length and somewhat longer than lst joint; 5 first articles of the funicle 

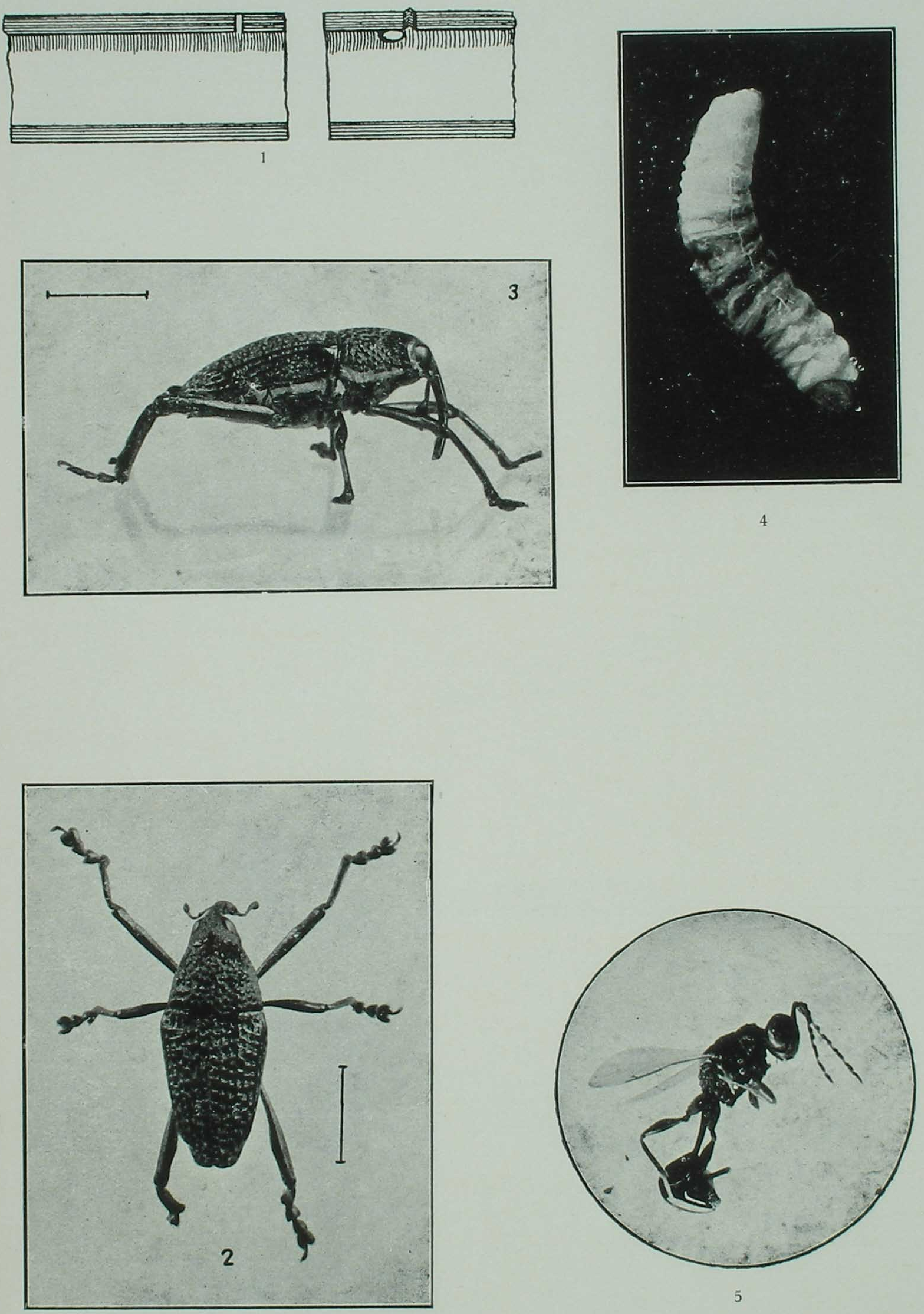

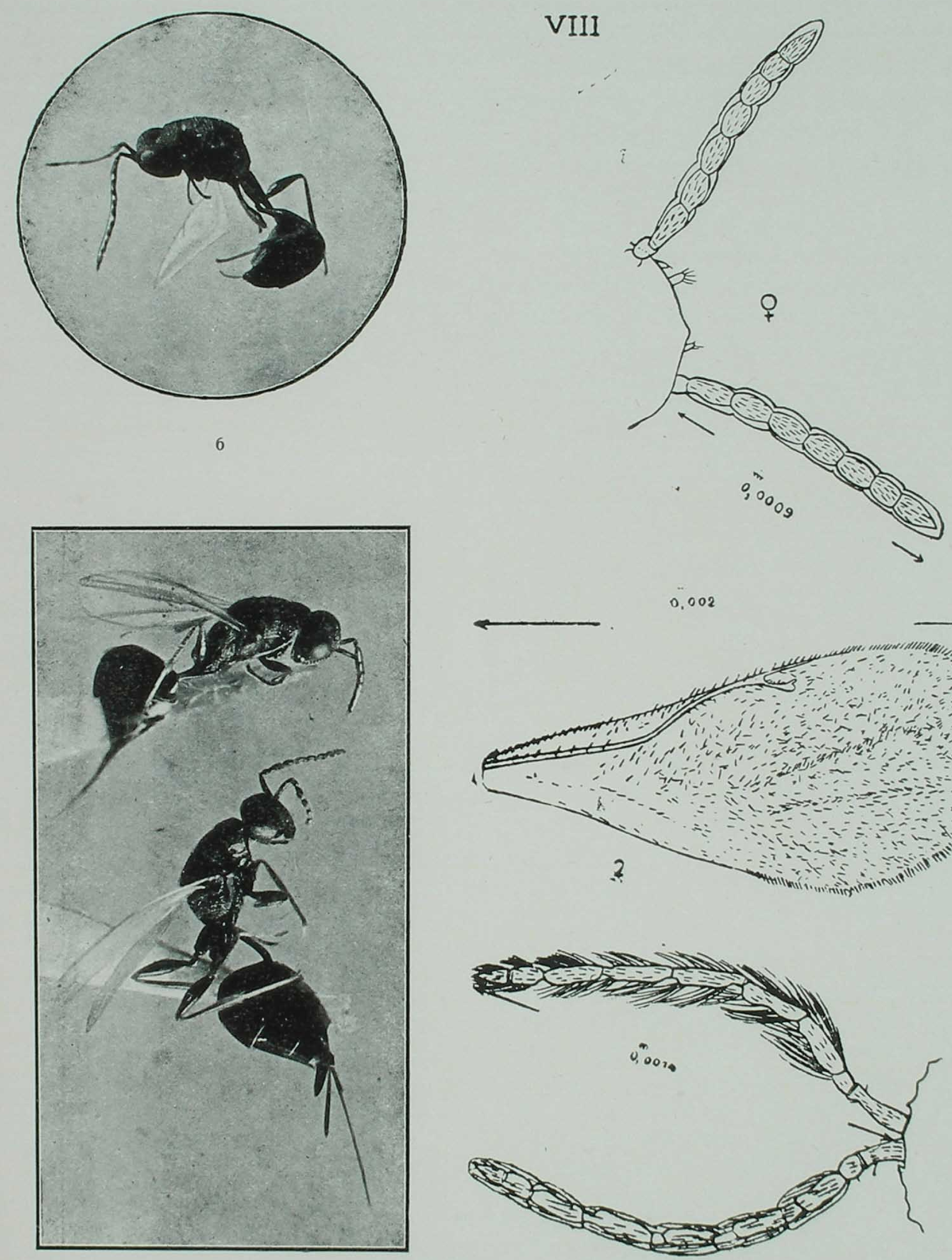

0,002
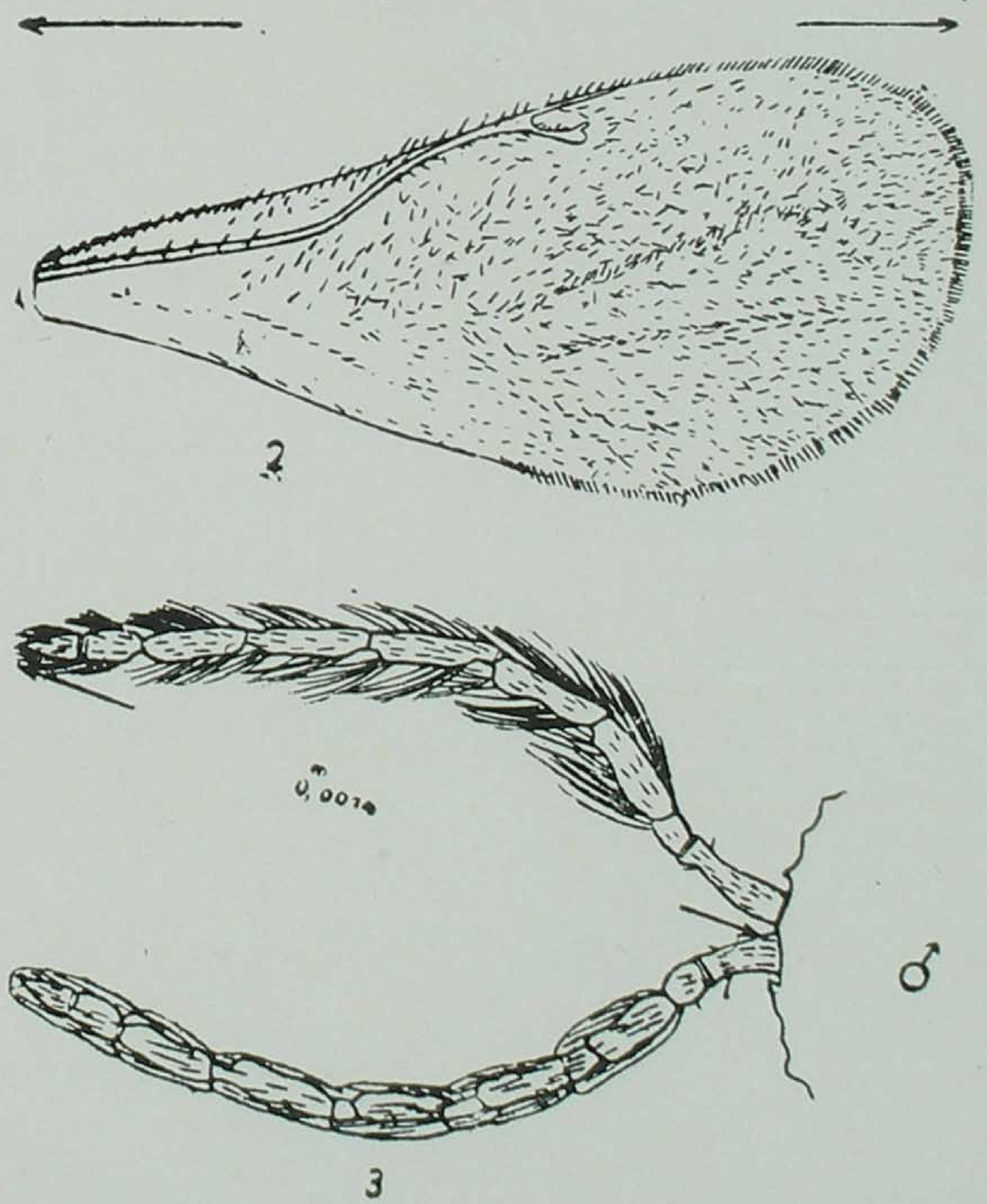
primeiros articulos do funiculo apresentam, cada um, uma concavidade na borda interna e em cada extremidade pêlos com o comprimento aproximadamente igual ao do articu10 ; articulo terminal articulado: parte basal cilindroide, parte apical conoide.

Ocelo mediano um pouco adiante dos lateraes, na extremidade superior, dentro das depressões antenaes.

Pernas com pubescencia prateada.

Abdome, incluindo o peciolo, pouco mais comprido do que cabeça e torax reunidos, liso e muito brilhante nos 6 primeiros segmentos; os demais segmentos com fina pubescencia branca; peciolo pouco mais curto que o torax; 4 o segmento, mais comprido de todos.

Comprimento: de $2,75 \mathrm{~mm}$. a 3,25 $\mathrm{mm}$.

Femea (Fig 6). Cor igual a do macho.

Antenas com funiculo de 7 articulos; escapo um pouco maior que o pedicelo $t o$ 10 articulo do funiculo reunidos; 10 articulo do funiculo oblongo-ovoide, maior que o dobro do pedicelo; $2^{\circ}, 3^{\circ}, 4^{\circ}, 5^{\circ}$ e $6^{\circ}$ ovoides, aproximadamente com o mesmo comprimento e ım pouco mais curtos que o 10 .

Abdome (incluindo o peciolo) mais comprido que a cabeça e o torax reunidos, com o ultimos segmentos ponteagudo e com um oviscapto de comprimento medio; os 6 primeiros segmentos e o 80 lisos e brilhantes; 70 e 90 pubescentes,

Comprimento: de $3,00 \mathrm{~mm}$. a $3,75 \mathrm{~mm}$.

Tipo na coleção do Instituto.

No alto da Boa-Vista, Tijuca, (Rio) encontrei uma especie de bambú, com colmo muito semelhante ao da cana da India, que é atacado pelo Erethistes lateralis BHN.

No material que colhi consegui obter tambem alguns exemplares de Prodecatoma cru$z i$.

Recebi tambem uma imajem de Erethistes lateralis apanhada no Sumaré (Serra da Tijuca) pelo Snr. R. FISCHER.

Ha outros coleopteros que attacam a cana da India. O tenebrionideo Acropteron rufipes Perty (Delec. show an escavation on the inner margin and on both ends bristles of the length of the joint; terminal joint articulated, the basal segment cylindrical, the apical one conical.

Median ocellus somewhat in front of the lateral ones, inside of the upper end of the antennal furrow.

Legs with silvery pubescence.

Abdomen (including petiole) somewhat longer than head and thorax together; 6 first segments smooth and shiny; the other segments with a short white pubescence; petiole somewhat shorter than the thorax; 4th segment the longest of all.

Length. 2,75 mm. 3,25 $\mathrm{mm}$.

Female. (Fig. 6) Of the same colour as the male. Funicle of the antennae with 7 joints. Scape somewhat longer than pedicellus and lst joint of the funicle; lst article of the funicle of alongated egg shape, its length more than double the length of the pedicellus; 2nd, 3rd, 4th. 5th and 6 th ovate, nearlly equal and somewhat shorter than first joint.

Abdomen (including petiole) longer than head and thorax joined showing a pointed last segment and an oviscapt of medium length; first 6 segments and 8th segment smooth and shining; 7th and 9th pubescent.

Length. $3 \mathrm{~mm}$. $3,75 \mathrm{~mm}$.

Type in the collection of the Institute.

Eggs and larvae, probably of the same beetle Erethistes lateralis were found by me at Alto da Boa Vista, Tijuca mountains, (Rio) in another bamboo species having stems of the same thickness but much longer than indian cane and with prickly stipulae.

Some samples kept for observation furnished a few specimens of Prodecatoma Cruzi.

An imago of Erethistes lateralis was brought to me by Mr. R. FISCHER. It came from Sumaré (Tijuca Mountains).

The indian cane is attacked by anoter coleoptera; the tenebrionid Acropteron rufipes Perty (Delectus ani- 
tus animalium articulatorum, pg. 65. Tab 12, fig. 8) devora-lhe os brotos

Um lamelicornio (Bolax sp.?) alimenta-se das folhas desta planta. Esta especie quanto ao tamanho e fórma do corpo é igual ao Bolax flaveolus Champ., apresenta, entretanto, na cabeça, pronoto e elitras, as mesmas cores do $B$. magnus Champ.

\section{Manguinhos, Março 1914.}

malium articulatorum, pg. 65 , tab. 12 , fig. 8) feeds on its schoots; also a lamellicornian beetle (Bolax sp.?) consumes the leaves of this plant This species in length and body shape equals the $B$. flaveolus Champ., but shows on head, pronotum and elytra the same colouring than B. magnus Champ.

Manguinhos, March 1914. 


\section{Explicação das figuras.}

I. Fragmentos de bambú: a) mostra a perfuração feita pelo rostrum do Erethistes e no interior o ovo; b) mostra o buraco deixado pelo Prodecatoma.

II. Erethistes lateralis.

III. Erethistes lateralis.

IV. Larva de E. lateralis um tanto aumentada.

V. Prodecatoma Cruzi, ơ, (aumentado) criado n'um ovo de Erethistes de Petropoiis.

VI. Prodecatoma Cruzi, ó, (aumentado) criado n'um ovo de Erethistes do alto da Tijuca). das).

VII. Prodecatoma Cruzi $\$$, + , (aumenta-

VIII. Antenas e aza anterior do Prodecato ma Cruzi.

\section{Explanation of the figures.}

I. Fragments of bamboo stem; $\boldsymbol{a}$ ) shows the perfuration made by the rostrum of Erethistes and the egg inside; $b$ ) shows the hole for exit made by the Prodecatoma.

II. Erethistes lateralis.

III. Erethistes lateralis.

IV. Larva of $E$. lateralis somewhat enlarged.

V. Prodecatoma Cruzi, ơ (enlarged), bred of egg of Erethistes, from Petropolis.

VI. Prodecatoma Cruzi, ó, (enlarged) bred of egg of Erethistes from alto da Tijuca.

VII. Prodecatoma Cruzi, 우, ㅇ (enlarged).

VIII. Antennae and front wing of $P$. cruzi. 